\title{
The Application of Quality Function Deployment (QFD) Towards The Design of Batik Coloring Machines to Increase The Value of Fading and Stains on Fabrics
}

\author{
Siswiyanti ${ }^{1 \mathrm{a}}$, Rusnoto $^{1 \mathrm{~b}}$, Saufik Luthfianto ${ }^{1 \mathrm{c}}$, Nurjanah $^{1 \mathrm{~d}}$
}

\begin{abstract}
The aim of this study is to design a batik coloring machine using the Quality Function Deployment (QFD) method in order to increase the value of fading and stains on fabrics. It can be concluded that the results of the design of batik coloring machines according to the application of QFD have 3 rollers/cylinders and propulsion about $0.190 \mathrm{HP}$ with the working concept of a sheet of cloth wrapped around the cylinder with rotation of $72.5 \mathrm{rpm}$. There are significant differences between variables in the design before and after the experiment on the batik value quality analysis of soap washing and desecration of unbleached plain cloth of Primisima type, Gamelan stamp. The average difference between before and after the experiment is 0.060 or increase to $6 \%$, while for the analysis of batik quality test, the value of rubbing dry and wet cloth has a mean difference between before and after the experiment of 0.100 or an increase of $10 \%$. Standard time generated from the measurement process using a machine dipping carried out by 20 batik makers has a value of 0.2701 hours/ unit with total output of 4 units/ hour, while standard time for coloring activities that uses a bucket dip is 0.5346 hours / unit with total output of 2 units/ hour.
\end{abstract}

Keywords. batik, coloring machine, quality function deployment

\section{INTRODUCTION}

The coloring activity for dyeing process of hand-drawn batik in the batik center of Tegal City of Indonesia is generally carried out by women using a bucket or tub. The dyeing activity must be done repeatedly to produce good quality or fade-proof batik cloth. In the dyeing process, both hands of the worker go into the bucket or tub within range of about $75 \mathrm{~cm}$ and the body posture is stooped. The interview with the batik makers in Fitri Ayu Kalinyamat Wetan batik group in Tegal City reveals that batik coloring activity needs skill to mix the ingredients/ dyes with water, in the sense that too much thickness in the process of mixing naptol dyes with water can cause uneven coloring. The dyeing process requires energy and carefulness because the

\footnotetext{
1 Jurusan Teknik Industri, Universitas Panca Sakti Tegal, Jl. Halmahera KM. 01, Tegal

a email: siswieyanti@gmail.com

b email: rusnoto74@gmail.com

c email: saufik34@yahoo.com

d email: nur_janah1963@yahoo.com
}

fabric must be dyed repeatedly and turned backwards so that the dye can penetrate evenly into the fabric. The cleanliness should also be maintained because hasty work attitude can cause bad quality and dirty hands also result in dirty cloth.

The process of making batik in the Fitri Ayu batik group is done through a number of processes, starting from making patterns on paper, making patterns in cloth, nyanting, isenisen, nembok, coloring to scratching and washing. The coloring process requires 30 minutes per cloth per 1 color. In case one cloth has more than one motif, the coloring process is multiplied by the number of the color.

According to (Rizky \& Trilaksana, 2015), batik process is carried out through several steps starting from motive formation, coloring/ dyeing, fixation and scratching. The dyeing process is one of determining factors of batik quality (Suliyanto et al., 2015). With regard to this, it is found that the use of naphthol dyes can improve color naphthol soap by $8 \%$ (Luthfianto et al., 2014). For dark colors and alum, it is found that the optimal condition of dyeing to obtain sharp colors are 5 and 8 times abd 11 times of dyeing, respectively (Pujilestari, 2017). High temperature can cause batik wax melted and the melting condition, in 

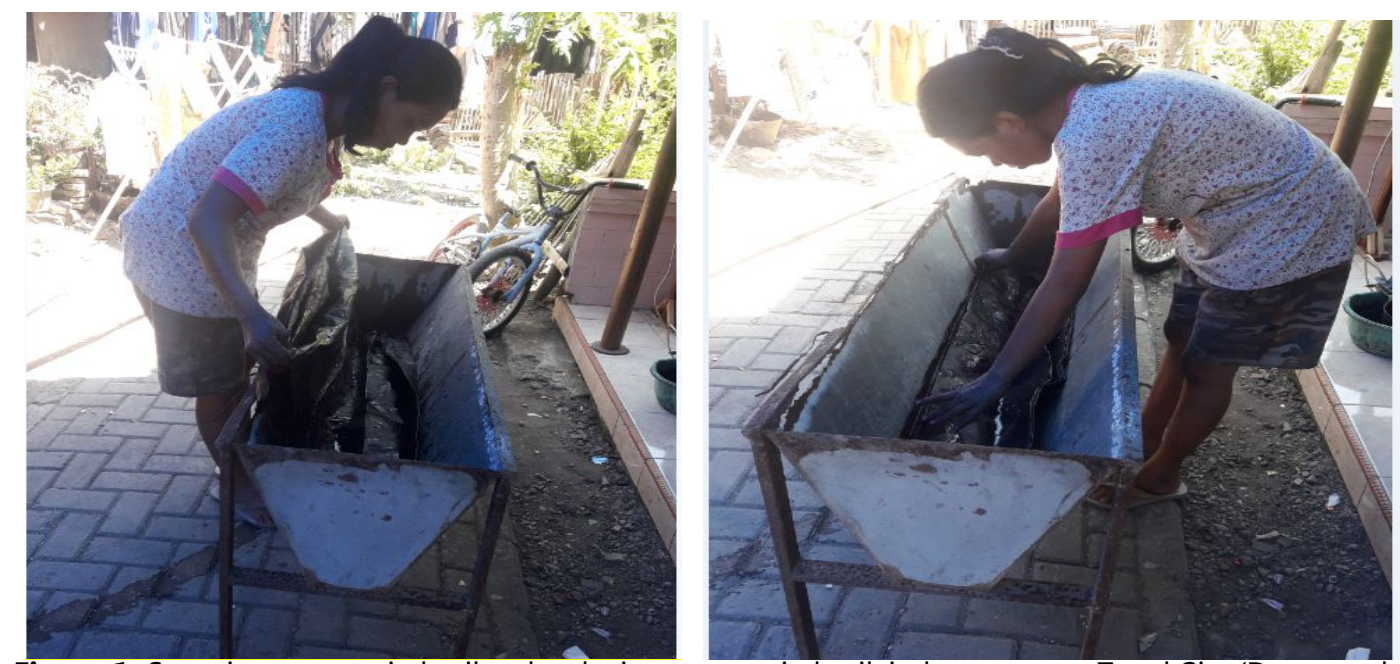

Figure 1. Stooping posture in batik color dyeing process in batik industry center Tegal City (Dyes are the assistance of the Tegal City Government)

turn, causes damage on batik motifs (Pujilestari et al., 2016). The heated Batik wax will emit smoke containing gas $\mathrm{NO} 2, \mathrm{SO} 2, \mathrm{CO}, \mathrm{CO} 2, \mathrm{HC}, \mathrm{H} 2 \mathrm{~S}$. The presence of these pollutants is harmful to workers' health and the environment (Latif et al., 2016). The implementation of RULA on shaking method of dyeing at Rumah Batik Komar recommends an improvement and further investigation (Pratama et al., 2015). On dyeing or coloring activities using a manual or traditional instrument (in this case, bucket), the application of REBA leads to the need of immediate repair (Siswiyanti \& Rusnoto, 2018). In the meantime, the implementation of RULA on the same activities suggests immediate repair as well (Siswiyanti \& Rusnoto, 2017). According to (Ma'ruf et al., 2015), the batik color dipping tool has a size of $1610 \mathrm{~mm} \times 650 \mathrm{~mm} \times 460 \mathrm{~mm}$ with a drive system of an electric motor $1 / 4 \mathrm{HP}, 1: 60$ reducer with rotation generated of $9 \mathrm{rpm}$ and 186 watts. This tool setting increases batik fabric production capacity around 5 pieces per day to 8 pieces per day and speeds up the coloring process to 30 minutes per sheet. In terms of designing batik dyeing machines, the use of two rollers of which drive rotation is $47 \mathrm{rpm}$ produces $0.019 \mathrm{HP}$ driving motor power. The same machine can produce the evenly colored fabric and the relatively low motor power is suitable for small batik industries (Sanjoto et al., 2016). The coloring of batik cloth can be more evenly improved by designing appropriate technology, an example of which is the application of feeder machines in small batik industries in Pekalongan. Using the feeder machines, the dyeing of batik cloth with a length of more than $2.5 \mathrm{~m}$ can be carried out easier with more even colors, less coloring time, improved work posture and increased sales (Irhandayaningsih, 2017). Based on the aforementioned problem description, this paper deals with the design of coloring machines in order to increase the value of fading and stains on fabrics by using Quality Function Deployment method.

\section{RESEARCH METHODS}

This research uses Quality Function Deployment which consists of four stages, namely planning and preparation of customer voting and the making of quality house; development of part deployment matrix; process planning matrix; and production planning matrix. The research took place at Fitri Ayu batik group which is located in batik industry center in Kalinyamat Wetan, Tegal City, Indonesia.

The tools used in this research are: 3 PVC rolls/ cylinder pipe with a driving force of $0.190 \mathrm{HP}$, the working concept of sheet cloth wrapped around the cylinder with rotation of $72.5 \mathrm{rpm}$, iron paint, digital camera and questionnaires (Siswiyanti \& Rusnoto, 2018). Questionnaiare 1 is to determine attributes/ characteristics of product the user 
Table 1. The characteristics of Desires / Needs for Batik Coloring Machine Customers

\begin{tabular}{|c|c|c|}
\hline Primary & Secondary & Tertiary \\
\hline \multirow[t]{5}{*}{$\begin{array}{l}\text { Batik coloring } \\
\text { machine } \\
\text { product design }\end{array}$} & Easy to use & $\begin{array}{ll}- & \text { Easy to operate } \\
\text { - } & \text { Easy to move } \\
\text { - } & \text { Easy to dip dye } \\
\text { - } & \text { Easy to clean and dispose of dyes }\end{array}$ \\
\hline & Safe to use & $\begin{array}{ll}\text { - } & \text { Safety of undamaged dyes } \\
\text { - } & \text { undamaged Fabric safety } \\
\text { - } & \text { Safety of dyes for processing }\end{array}$ \\
\hline & Comfortable to use & - Comfort when used \\
\hline & Precision & $\begin{array}{ll}- & \text { Suitability size of tools / machines with cloth } \\
\text { - } & \text { Suitability of the shape of a tool / machine with cloth }\end{array}$ \\
\hline & Good result & $\begin{array}{l}\text { - } \quad \text { Color quality, quality of quantity } \\
\text { - } \quad \text { Quality of time, Quality of process }\end{array}$ \\
\hline
\end{tabular}

Source: Results of user voting analysis

Table 2. The result of validity test

\begin{tabular}{|c|c|c|c|c|c|}
\hline \multicolumn{6}{|c|}{$\mathrm{N}=20 ; \mathrm{df}=18 ; \alpha=5 \%$} \\
\hline \multirow{3}{*}{ CUSTOMER'S NEED } & \multirow{2}{*}{\multicolumn{2}{|c|}{ r Satisfaction count }} & \multirow{3}{*}{$\begin{array}{c}c \\
\text { Interest } \\
\text { count } \\
\text { Batik } \\
\text { coloring } \\
\text { machine }\end{array}$} & \multirow{3}{*}{ r Table } & \multirow{3}{*}{ Conclusion } \\
\hline & & & & & \\
\hline & $\begin{array}{c}\text { Batik } \\
\text { coloring } \\
\text { machine }\end{array}$ & $\begin{array}{c}\text { Manual } \\
\text { batik } \\
\text { coloring }\end{array}$ & & & \\
\hline Easy to operate & .628 & .812 & .678 & 0,468 & Valid \\
\hline Easy to move & .615 & .789 & .703 & 0,468 & Valid \\
\hline Easy to dip dye & .595 & .796 & .659 & 0,468 & Valid \\
\hline Easy to clean and remove dyes & .632 & .791 & .694 & 0,468 & Valid \\
\hline Safety of undamaged dyes & .603 & .816 & .669 & 0,468 & Valid \\
\hline Undamaged Fabric safety & .605 & .831 & .649 & 0,468 & Valid \\
\hline Safety of dyes for processing & .695 & .773 & .692 & 0,468 & Valid \\
\hline Comfort when used & .620 & .806 & 699 & 0,468 & Valid \\
\hline Suitability size of tools / machines with cloth & .643 & .793 & .657 & 0,468 & Valid \\
\hline Suitability of the shape of a tool / machine with cloth & .709 & .823 & .671 & 0,468 & Valid \\
\hline Color quality & .675 & .826 & .701 & 0,468 & Valid \\
\hline Quality of quantity & .662 & .824 & .660 & 0,468 & Valid \\
\hline Quality of time & .634 & .823 & .693 & 0,468 & Valid \\
\hline Quality process & .725 & .841 & 699 & 0,468 & Valid \\
\hline
\end{tabular}

Source: The Analysis Results of SPSS 23.0

needs, whereas questionnaire 2 is concerned with the satisfaction and importance of the characteristics. The respondents in this study were 20 female batik makers aged between 20 and 55 years, with at least one year of experience, in good health, and are willing to participate in the research till completion.

\section{RESULT AND DISCUSSION}

Table 1 explains the characteristics of the users of batik coloring machines, whereas the results of validity and reliability test can be seen in Table 2 and Table 3.

The final result of the QFD method is a product development plan located at the bottom of the House of Quality (HOQ). The QFD method covers complete processes starting from identifying problems to achieving the target of development projects through the existence of design specifications. The technical characteristic is used to measure or quantify consumer needs. The level of importance can be known based on 
Table 3. The results of sampling reliability test and satisfaction (Batik coloring machine and manual batik coloring)

\begin{tabular}{lcc}
\hline \multicolumn{1}{c}{ Item } & $\square$ (Alpha) & Notes \\
\hline Level of importance & 0,697 & Reliable \\
Satisfaction Level of Batik Coloring Machine & 0,666 & Reliable \\
Satisfaction Level of Coloring Batik Manual & 0,823 & Reliable \\
\hline Source: The Analysis Results of SPSS 23.0 & &
\end{tabular}

Table 4. Part deployment matrix

\begin{tabular}{|c|c|c|c|c|c|c|c|}
\hline Technical Requirement & Target & 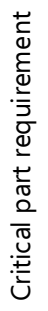 & 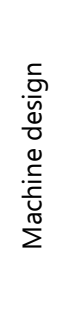 & $\begin{array}{l}\frac{c}{0} \\
\frac{0}{0} \\
\frac{0}{0} \\
\frac{0}{0} \\
ن\end{array}$ & 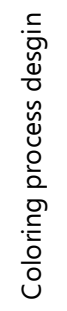 & $\begin{array}{l}\frac{.}{0} \\
\frac{0}{0} \\
\frac{0}{0} \\
0 \\
\cdot \frac{c}{0} \\
\stackrel{0}{0}\end{array}$ & 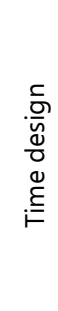 \\
\hline Functional machine & 3 cylinders (dia 3/4 ') for fabric rotation balancer & 9 & $\cdot$ & & $\cdot$ & & $\cdot$ \\
\hline Raw material for machine makers & Electrical Motor 1/4 HP dan b, box electric & 7 & - & & & - & \\
\hline Quality of dyeing & 3 cylinders (dia 3/4 ') for fabric rotation balancer & 6 & & & & - & • \\
\hline \multirow[t]{3}{*}{ Coloring quality } & adjusted color absorbency and fabric, bubbles & 5 & & • & • & & \\
\hline & & & 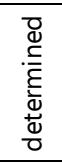 & 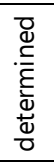 & 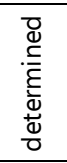 & $\begin{array}{l}\bar{D} \\
\stackrel{d}{E} \\
\frac{E}{d} \\
\frac{d}{d} \\
\frac{d}{0}\end{array}$ & 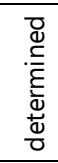 \\
\hline & & & 144 & 45 & 126 & 117 & 135 \\
\hline
\end{tabular}

the order of the value, namely 4.95 for the "color quality" attribute, 4.40 for the "time quality" attribute, 4.40 for the "easy to clean and dispose of dyes" attribute, 4.30 for "comfort when used" attribute, 4.25 for the "easy to move" attribute, 4.20 for the "total quality" attribute and 4.20 for the "process quality" attribute.

\section{Part Deployment Matrix}

In the part deployment matrix (see Table 4), there are 4 targets namely 3/4-inch-diameter 3 cylinders for balancing cloth rotation, $1 / 4 \mathrm{HP}$ electrical motor, electric box, 3 cylinders and adjusted for color and color absorption power as well as bubble hose, with each critical part requirement $9.7,6$ and 5 with the highest score of 144 in engine design.

\section{Process Planning Matrix}

The process planning matrix (see Table 5) begins with making a map on the process of making batik coloring machine. The map is then connected with the critical part resulted from the previous matrix. There are 5 stages of the planning process, namely the process frame installation, big tub installation, lower cylinder installation, cylinder upper and electric motor installation.

\section{Production Planning Matrix}

This step is the last step to find out the actions that need to be taken to improve product design performance. The steps that require improvement can be seen in Table 6 .

\section{The analysis of Batik Coloring Machine Components}

Using the QFD method, main components of Batik coloring machines affecting the quality of fabrics are found, as follow: (1) leg supporting screw is to regulate the slope of the tub to facilitate the process of disposal of dyes; (2) a small roll of cloth pressure/ load that helps the process of pressing fabric so that the liquid absorbs easily on the fabric; (3) the inventer box which is used to select the swivel/ speed; (4) the channel and faucet of the dyestuff of which 
Table 5. Planning matrix for the process of making batik coloring machines

\begin{tabular}{|c|c|c|c|c|c|c|c|}
\hline $\begin{array}{c}\text { Specification process large } \\
\text { cylinders cylinder on motor } \\
\text { electronics }\end{array}$ & 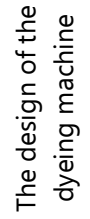 & $\begin{array}{l}\text { 을 } \\
\pm .0 \\
.00\end{array}$ & 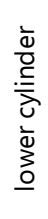 & 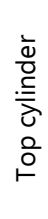 & 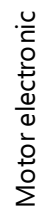 & $\begin{array}{l}\text { Critical part } \\
\text { requirement }\end{array}$ & Planning process \\
\hline Manual & - & 0 & 0 & 0 & - & Measurement process & \\
\hline Meter roll & - & 0 & 0 & 0 & - & Tools used & \\
\hline Iron the size & 0 & - & - & - & 0 & Material size & Framework Process 1 \\
\hline customized with design & 0 & 0 & - & - & - & Cutting method & \\
\hline Hacksaw & - & 0 & - & - & - & Tools used & \\
\hline Customized design & 0 & - & - & - & - & Welding method & \\
\hline Electric welding & 0 & - & - & - & - & Tools used & \\
\hline Manual & - & 0 & - & - & - & Assembly process & Installing a big tub 2 \\
\hline $\begin{array}{l}\text { Painting, supporting pipes, } \\
\text { bolts, nuts, rings }\end{array}$ & 0 & - & - & - & - & Tools used & \\
\hline Manual & - & - & 0 & 0 & - & Assembly process & Installing lower cylinder 3 \\
\hline Machine frame, bulkhead tub & 0 & - & - & - & - & Tools used & \\
\hline Manual & - & 0 & 0 & 0 & 0 & Assembly process & Installing upper cylinder 4 \\
\hline Lower engine frame & 0 & - & - & - & - & Tools used & \\
\hline Manual & - & - & - & - & 0 & Assembly process & \\
\hline Upper engine frame & 0 & - & - & - & - & Tools used & \\
\hline Manual & - & - & - & - & - & Assembly process & \\
\hline Safety cap, van belt 1,2,3 & 0 & - & - & - & 0 & Tools used & \\
\hline Manual & - & - & - & - & - & Assembly process & \\
\hline Fasteners, bearing units & 0 & - & - & - & 0 & Tools used & \\
\hline Manual & - & - & - & - & - & Assembly process & \\
\hline Cylinder axle & 0 & - & - & - & - & Tools used & Motor electric 5 \\
\hline Manual & - & - & - & - & - & Assembly process & \\
\hline Pulley drive cylinder & 0 & - & - & - & - & Tools used & \\
\hline Manual & - & - & - & - & - & Assembly process & \\
\hline Cylindrical pulley is driven & 0 & - & - & - & 0 & Tools used & \\
\hline Manual & - & - & - & - & - & Assembly process & \\
\hline Pulley motor & 0 & - & - & - & - & Tools used & \\
\hline Manual & - & - & - & - & - & Assembly process & \\
\hline Gear box & 0 & - & - & - & - & Tools used & \\
\hline Manual & - & - & - & - & 0 & Assembly process & \\
\hline 4 inch pulley driven & 0 & - & - & - & 0 & Tools used & \\
\hline Manual & - & - & - & - & 0 & Assembly process & \\
\hline 6 inch pulley driven & 0 & - & - & - & 0 & Tools used & \\
\hline Manual & - & - & - & - & - & Assembly process & \\
\hline Compressor, pipe bulb & 0 & - & - & - & - & Tools used & \\
\hline Manual & - & - & - & - & 0 & Assembly process & \\
\hline Switch, socket, cable & 0 & - & - & - & 0 & Tools used & \\
\hline
\end{tabular}

Source: Siswiyanti \& Rusnoto (2018)

function is to facilitate the process of removing the dye and to reduce the stooping posture (Table 7).

\section{The analysis of Standard Time per unit of Product}

The normal time obtained from the measurement process, especially from coloring activities by using machine of dyes that is performed by 20 batik makers has an average value of 14.5 minutes/ unit with a performance rating level 0.95 . Standard time per unit of product is 0.2701 hours/ unit so that the total output is 4 units/ hour (assuming 15\% allowance value, $5 \%$ accuracy rate and $95 \%$ confidence level). 
At the same performance rating level, it is found that the normal time for coloring activities by using bucket dipping carried out by 20 batik makers has an average value of 28.7 minutes/ unit. Assuming 15\% allowance value, 5\% accuracy rate and $95 \%$ confidence level, standard time per product unit is 0.5346 hours/ unit so that the total output is 2 units/ hour.

\section{The analysis of the Difference Test towards the Washing of Soap and Blasphemy Test}

The results of color fade-proof and soap washing value using variations in pulley diameter D100, D125, D150 and D175 are presented in Table 8.

Table 8. The analysis results of the Quality Test of Batik on unbleached plain fabrics Primisima Gamelan stamp The Value of Washing Soap and Blasphemy

\begin{tabular}{ccccc}
\hline Manual & D100 & D125 & D150 & D175 \\
\hline 4 & 4 & 4,5 & 4,5 & 4,5 \\
4 & 4 & 4,5 & 4,5 & 4,5 \\
4,5 & 4 & 4,5 & 4,5 & 4,5 \\
4,5 & 4 & 4 & 3,5 & 3 \\
4 & 4 & 4,5 & 3,5 & 3 \\
4 & 4 & 4,5 & 3,5 & 3,5 \\
\hline \multicolumn{5}{c}{ Data source: textile evaluation lab test results of UII } \\
\multicolumn{5}{c}{ Yogyakarta, 2018 }
\end{tabular}

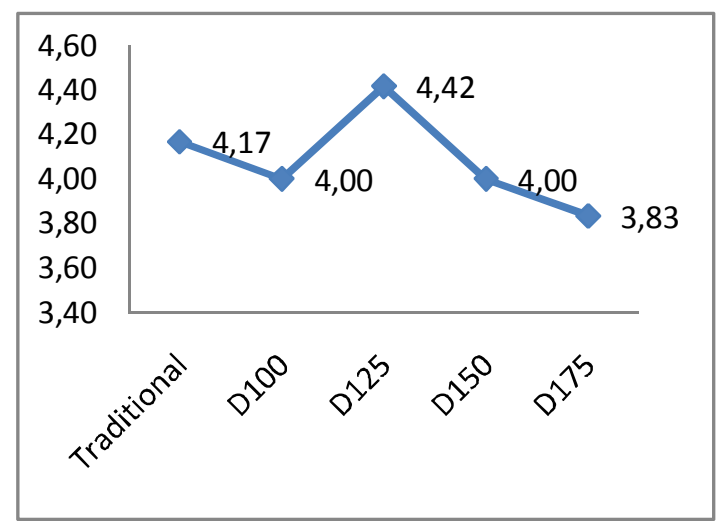

Figure 2. The average fade and stain test value

Table 9. Average, standard deviation and t test between before and after experimental design

\begin{tabular}{crrrr}
\hline Variable & Average & $\begin{array}{c}\text { Deviation } \\
\text { Standart }\end{array}$ & T count & $P$ \\
\cline { 1 - 3 } Before & 4.167 & .2582 & -1.464 & .003 \\
\hline After & 4.417 & .2041 & & \\
\hline
\end{tabular}

From the normality test, it is found that all data are normally distributed. The results of $t$ test for objects are shown in the manual machine using D125 (see Table 9), because they have the largest difference on the average after the experiment. Table 6 states that, regarding the test with respect to before and after the experiment in the sample, the probability value is 0.003 ( $p$ $<0.05$ ). Thus it can be concluded that there are significant differences between the variables in the design before and after the experiment. The average difference before and after the experiment is 0.060 or an increase of $6 \%$.

\section{The Analysis of Different Tests towards Rubbing Tests of dry and wet fabrics}

The results of dry and wet cloth rubbing fadeproof values which use variations in pulley diameter D100, D125, D150 and D175 are provided in Table 10.

It is found that all data are normal distributed. The test for difference used is paired sample $t$ test applied to the D125 (for the reason that they have differences in the mean on the average after the experiment, see Table 8).

Table 11 states that, regarding the test with respect to before and after the experiment in the sample, the probability value is $0,000(p<0.05)$. It can therefore be concluded that there are significant differences between the variables in the design before and after the experiment. The average difference before and after the experiment is 0.100 or an increase of $10 \%$.

Table 10. The analysis results of the quality test of batik on unbleached plain fabrics primisima gamelan stamp the value of rubbing dry and wet cloth

\begin{tabular}{ccccc}
\hline Manual & D100 & D125 & D150 & D175 \\
\hline 3,5 & 3 & 3,5 & 3 & 4 \\
3,5 & 3 & 4 & 3,5 & 3,5 \\
3 & 3 & 3,5 & 3,5 & 3,5 \\
3,5 & 3,5 & 3,5 & 3 & 3,5 \\
3,5 & 3,5 & 4 & 3 & 3,5 \\
3 & 3,5 & 3,5 & 3 & 3,5 \\
\hline
\end{tabular}

Data source: textile evaluation lab test results of UII Yogyakarta, 2018 


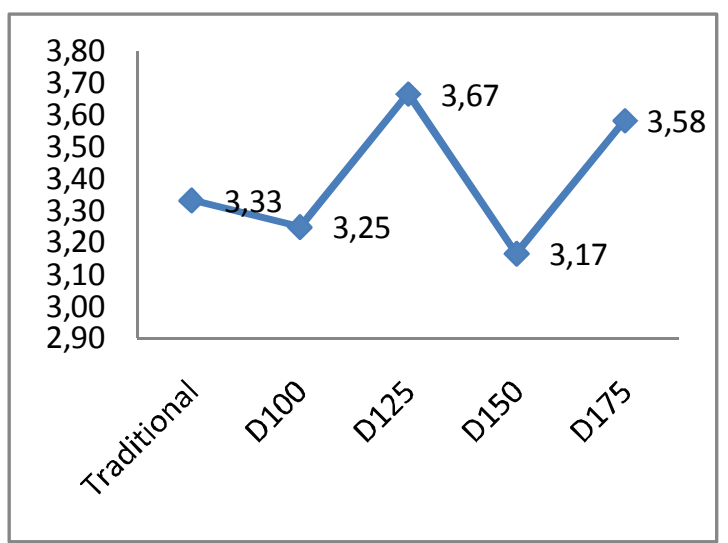

Figure 3. The Average Value of Rubbing dry and wet cloth

Table 11. The average, standard deviation and test between before and after design

\begin{tabular}{|c|c|c|c|c|}
\hline Variable & Average & $\begin{array}{c}\text { Deviation } \\
\text { standart }\end{array}$ & $\begin{array}{c}\mathrm{t} \\
\text { count }\end{array}$ & $P$ \\
\hline Before & 3.333 & .2582 & - & \\
\hline After & 3.667 & .2582 & 3.162 & 000 \\
\hline
\end{tabular}

\section{CONCLUSION}

From the results of data processing and data analysis that have been conducted, it can be concluded that there are 14 attributes of ergonomic interests as the source of ideas for designing batik coloring machines, namely easy of operation, easy of transfer, easy of dyeing, easy of cleaning and removing dyes, the safety of the dyes is easily not damaged, the safety of the fabric is not easily damaged, the safety of the dyes to be processed, the comfort when used, the suitability of the tools/ machines with the fabric, the suitability of the machine / fabric, color quality, quality of quantity, quality of time, process quality.

Based on the Analysis of batik quality test on unbleached plain fabric Primisima Gamelan stamp has TLW Value on Soap Washing and Blasphemy, it can be concluded that there are significant differences between the variables in the design before and after the experiment. The average difference before and after the experiment is 0.060 or an increase of $6 \%$.

Regarding unbleached Plain Fabric Primisima Gamelan stamp has TLW Value towards dry and wet cloth rubbing, it can be concluded that there are significant differences between the variables in the design before and after the experiment. The average difference before and after the experiment is 0,100 or an increase of $10 \%$.

From the measurement process using machine dye performed by 20 batik makers, it is found that the normal time has an average value of 14.5 minutes/ unit.

\section{ACKNOWLEDGMENTS}

The researcher thanked the Director General of Dikti and Kopertis, Region VI of Central Java for research funding through the Applied Product Grant program (DRPM DIKTI 2018, with contract number: 253/K/F/LPPM/UPS/III/2018) and all parties who assisted the process research. Hopefully this research is useful to add to the study of industrial engineering and mechanical engineering.

\section{DAFTAR PUSTAKA}

Irhandayaningsih, A. (2017). "Pengaruh penggunaan teknologi tepat guna dalam meningkatkan produktivitas UKM batik tulis di Kampung Batik Kauman Kota pekalongan". ANUVA, 1 (1), 11-18.

Latif, V.N.; Ristiawati; Istiqomah, N. (2016). "Profil potensi penyakit akibat kerja tahapan pembatikan". Unnes Journal of Public Health, 5 (4), 348-354.

Luthfianto, S.; Farid, A.; Siswiyanti. (2014). "Penerapan setting level optimal menggunakan metode taguchi pada proses produksi batik tulis untuk meningkatkan kualitas produk di sentra industri Batik Tulis Kalinyamat Wetan Kota tegal". Spektrum Industri, 12 (2), 113-247.

Ma'ruf, F.; Prasetya, A.; Mudjijana. (2015). "Modifikasi alat pencelup batik secara mekanis pada proses pembuatan batik tulis". Jurnal Teknika STTKD, 2 (1), 1-9.

Pratama, F.R.; Anugraha, R.A.; Sjafrizal, T. (2015). Pengembangan Detail Desain Alat Pencelupan Di Workstation Pewarnaan Di Rumah Batik Komar Development Of The Detail Design Dyeing Tools In Coloring Workstation At Rumah Batik Komar. In e-Proceeding of Engineering (Vol. 2, pp. 4495-4501). Retrieved from http://openlibrary.telkomuniversity.ac.id

Pujilestari, T. (2017). "Optimasi pencelupan kain batik katun dengan pewarna alam tingi (ceriops tagal) 
dan indigofera". Dinamika Kerajinan dan Batik, 34 (1), 53-62.

Pujilestari, T.; Pristiwati, E.; Atika, V.; Haerudin, A. (2016). "Pemanfaatan zat warna alam dari limbah perkebunan kelapa sawit dan kakao sebagai bahan pewarna kain batik". Dinamika Kerajinan dan Batik, 33 (1), 1-8.

Rizky, S.; Trilaksana, A. (2015). "Sejarah industrialisasi batik di Kampung Batik Jetis Sidoarjo tahun 1970-2013". Avatara, E-Journal Pendidikan Sejarah, 3 (3), 480-486.

Sanjoto, B.L.; Syafril, I.; Murwanti, S.; Subyakto, A., Husodo, N.; Surono, A.; Hakim, M.L. (2016). Penerapan Mesin Pewarnaan Kain Batik Tulis Pada Industri Kecil Peri Kecil Batik Bangkalan Madura. In Seminar Nasional Inovasi dan Aplikasi Teknologi Industri (Seniati) (pp. 61-65). Retrieved from

http://resits.its.ac.id/index.php/conference/1-

53147/Penerapan_Mesin_Pewarnaan_Kain_Batik_ Tulis_Pada_Industri_Kecil_Peri_Kecil_Batik_Ban gkalan_Madura

Siswiyanti; Rusnoto. (2017). Analisa Postur Kerja Pada Pewarnaan Batik Tulis (Celup Tradisional) Dan (Celup Mesin) Menggunakan Metode Rapid Upper Limb Assessment (Rula). In Proceeding SENDI_U (Vol. 0, pp. 263-172). Retrieved from http://www.unisbank.ac.id/ojs/index.php/sendi_ u/article/view/5052

Siswiyanti; Rusnoto. (2018). "Penerapan ergonomi pada perancangan mesin pewarna batik untuk memperbaiki postur kerja". Jurnal Optimasi Sistem Industri, 17 (1), 75-85.

Suliyanto; Novandari, W.; Setyawati, S. M. (2015). "Persepsi generasi muda terhadap profesi pengrajin batik tulis di Purbalingga". Jurnal Ekonomi dan Bisnis, 13 (1), 135-144. 